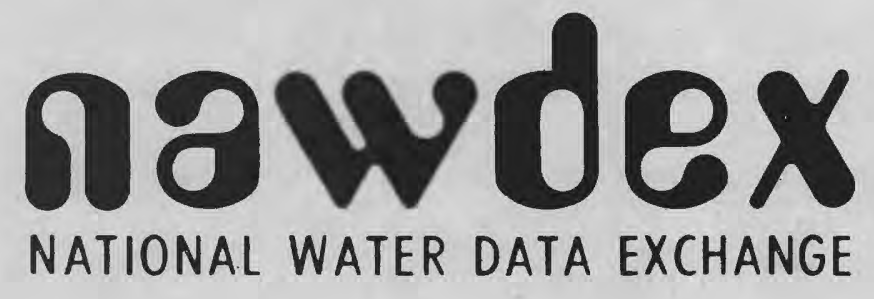

\title{
PROGRAM OBJECTIVES FOR THE NATIONAL WATER DATA EXCHANGE (NAWDEX) FOR FISCAL YEAR 1979
}

U.S. GEOLOGICAL SURVEY Open-File Report 78-975 


\title{
PROGRAM OBJECTIVES FOR THE NATIONAL WATER DATA EXCHANGE (NAWDEX) FOR FISCAL YEAR 1979
}

\author{
By MELVIN D. EDWARDS
}

U.S. GEOLOGICAL SURVEY

Open-File Report 78-975

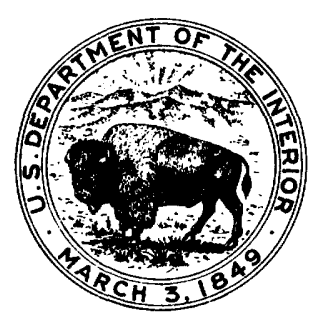




\section{U.S. DEPARTMENT OF THE INTERIOR \\ CECIL D. ANDRUS, Secretary \\ GEOLOGICAL SURVEY \\ H. William Menard, Director}

For additional information write to:

Chief Hydrologist

U.S. Geological Survey, WRD

421 National Center

Reston, Virginia 22092 


\section{CONTENTS}

Page

Abstract . . . . . . . . . . . . . . . . . . 1

Introduction . . . . . . . . . . . . . . . . . . 1

NAWDEX membership . . . . . . . . . . . . . . . 1

Program administration, management and coordination ..................... 2

NAWDEX services . . . . . . . . . . . . . . . 2

Identification of sources of water data . . . . . . . . 3

Indexing of water data . . . . . . . . . . . . . 4

Program and systems documentation . . . . . . . . . . 5

Recommended methods for the handling and
exchange of water data. . . . . . . . . . . . . 5

Training . . . . . . . . . . . . . . . . 6

Technical assistance . . . . . . . . . . . . . 6

Summary . . . . . . . . . . . . . . . . . 6 

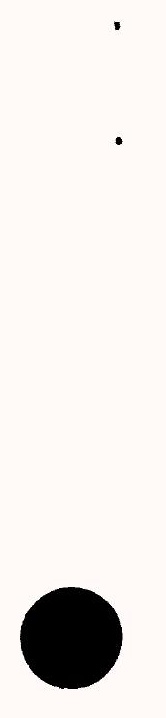
PROGRAM OBJECTIVES FOR THE NATIONAL WATER DATA

EXCHANGE (NAWDEX) FOR

FISCAL YEAR 1979

By Melvin D. Edwards

ABSTRACT

Th1s report desoribes the program objectives of the National Water Data Exchange (NAWDEX) for Fiscal Year 1979. These objectives include NAWDEX membership, program administration, management, and coordination, NAWDEX services, identification of sources of water data, indexing of water data, programs and systems documentation, recommended methods for the handling and exchange of water data, training, and technical assistance to NAWDEX members.

\section{INTRODUCTION}

This report describes proposed program objectives for the National Water Data Exchange (NAWDEX) for Fiscal Year 1979. These objectives are based upon a requested increase in the budget for the NAWDEX Program Office in Fiscal Year 1979. Congressional approval of the increase looks favorable. Member organizations will be informed of the final funding level when it has been established.

Many of the program objectives reflect recommendations made at the First MAWDEX Membership Conference held in Denver, Colorado on May 9-11, 1978. These recommendations are footnoted in the following paragraphs.

\section{NAWDEX MEMBERSHIP}

The Program office will cont Inue its efforts to increase NAWDEX membership to include all interested water-oriented organizations. Existing NALDEX members are urged to promote the NAWDEX concept among other prospective member organizations(*). The Program office plans the following tasks to assist the membership in this effort:

(1) A publication will be prepared to describe products and capabilities of systems associated with the NAWDEX data bases. This publioation will describe the Water Data Sources Directory and Master Water Data Index, software systems available to users, samples of actual products (reports, plots, etc.) that can be provided for NAWDEX users, and procedures available for obtaining services and assistance from NAWDEX Local Assistance Centers. This document will be used in support of the existing brochure entitled "NAWDEX - Key To Finding Water Data" which provides an overview of the NAWDEX program.

(2) A slide and cassette presentation will be developed describing the NAWDEX program(*). An effort will be made to develop this presentation

(*) Recommendation presented by ad hoc panels at the First NAWDEX Membership Conference. 
for use with easily transported hardware. The hardware and slides will be available on loan to members for use at conferences and meetings to describe NAWDEX to prospective members and users. The feasibility of developing a videotape presentation (*) for the same purpose will also be explored.

\section{PROGRAM ADMINISTRATION, MANAGEMENT AND COORDINATION}

The NAWDEX Program Office will continue to improve its communication and interaction with NALDEX member organizations. Several actions in this area are planned:

1. When desired, additional NAWDEX representatives may be designated by each member organization to facilitate dissemination of program material and to establish points of contact consistent with the organization and operational structure of member organizations (*).

2. The Membership Conference recommended that an ad hoc advisory group be established to provide guidance to the program and the Program Manager. This group, as proposed, would consist of member representatives selected from each of the categorles of NAWDEX member organizations: Federal, State, local government, interstate, academic, and private organizations. Such a group will have to be established in accordance with the Federal Advisory Committee Act (Public Law 92-463). The feasibility of establishing NAWDEX advisory mechanisms under the auspices of the Federal Interagenoy Advisory Committee on Water Data and the non-Federal Advisory Committee on Water Data for Public Use of the U.S. Geological Survey's office of Water Data Coordination is being studied. If feasible, an ad hoc NAWDEX advisory group will be established under the existing charters of these two committees.

3. The feasibility of establishing regional and additional state-wide NAWDEX organizations will be carefully evaluated during Fiscal Year 1979(*). This will be accomplished through close coordination with the NAWDEX membership.

4. Membership conferences will be held annually as described in the "Program of Operation for the National Water Data Exchange (NAWDEX)" (*). Locations of the conferences will be varied to better accomodate the participation of local members and the duration of each session will be restricted to two days. Members will be asked to recommend subjects in advance to be discussed by working panels. The next conference is tentatively scheduled for May 1979. Its location will be decided in late 1978.

\section{NAWDEX SERVICES}

NAWDEX will continue to expand its service capabilities. The Program Office will seek access to data systems that are nationwide in scope and, 
whore feasible, provide dissemination services for these systems.

The Program office w1ll make an effort to increase the participation of state-level natural resource information systems as Local Assistance Centers (*). Such major systems within the membership will be invited to become Local Assistance Centers and serve as state-based authorities on data availability to support the Centers maintained by the U.S. Geological Survey. Three such Centers currently serve in this capacity in Iowa, Texas and Virginia. Those organizations operating regional and national level information services which are not participating as Assistance Centers for NAWDEX will also be encouraged to promote NAWDEX as a part of their activities. These new Centers will work in conjunction with existing Centers and, thereby, provide a much expanded and more responsive level of service.

A policles and procedures manual, developed by the Program office to present guidelines for the operation of Local Assistance Centers, will be published and distributed to the membership (*). Also, additional information will be assembled on data systems, policies and procedures, fee schedules, and data dissemination capab1lities of member organizations (*). This Information will be made available in the Water Data Sources Directory, the Directory of Local Assistance Centers and other appropriate documents.

The Program office will develop mechanisms for providing feedback to NAWDEX relative to user needs (*). These mechanisms will define deficiencies in present systems to respond to user needs and, therefore, help to strengthen our capabilities to respond to these needs.

\section{IDENTIFICATION OF SOURCES OF WATER DATA}

The Water Data Sources Directory (WDSD) is an important part of the NAWDEX information base. To date, less emphasis has been given to the development of this data base due to the extensive personnel and funding requirements required in developing the Master Water Data Index (MWDI). Higher priority will be given to improving and expanding the contents of the WDSD during Fiscal Year 1979.

Work w11l be completed in early Fiscal Year 1979 on modifications to the WDSD to allow the inclusion of sources of water-related data. This will also include the implementation of improved software capability to provide for more flexible retrievals of information from the data base and the production of either a "Water Data Sources Directory," a "Directory of Water-Related Data Sources," or a "Combined Directory of Water and Water-Related Data Sources,"

Full-scale data-gathering activities for the WDSD can not begin until approval of the encoding forms and reporting procedures has been received from the Office of Management and Budget. This approval is not anticipated until mid or late Fiscal Year 1979. In an effort to obtain more complete 
information for the WDSD on all organizations for which data are contained in the Master Water Data Index (MWDI), two actions will be taken: (1) A software system will be implemented to update the WDSD with information for each organization regarding the number of sites for which data are indexed in the MWDI (*); and (2) Each organization will be furnished a printout showing the information currently contained in the WDSD and will be given the opportunity to amend or add to this information (*).

A dictionary of water-related data types will be developed in early Fiscal Year 1979 for use in the registration of sources of these data in the WDSD. Th1s dictionary will be included as a part of data-encoding instructions developed for the entry of data into the WDSD.

\section{INDEXING OF WATER DATA}

The Master Water Data Index (MWDI) remains as one of the most important program elements within NAWDEX. Emphasis will continue to be placed on the expansion of this data base. The following actions are planned for F1scal Year 1979:

1. The current MWDI data base structure will be reviewed and specifications for needed modifloations or additions to the contents and structure of the data base will be developed (*). Implementation of these changes during Fiscal Year 1979 will be based upon the availability of funds.

2. Design criteria and specifications will be developed for the Indexing of areal-related and non-point source water data (*). Implementation is planned for late Fiscal Year 1979 or early Fiscal Year 1980.

3. New encoding forms and instructions for the entry of data into the MWDI will be released for use by members upon their approval by the Office of Management and Budget (*).

4. Updates of the MWDI w111 continue with computerized interfaces developed to transfer information from the Storage and Retrieval (STORET) system of the U.S. Environmental Protection Agency and the National Water Data Storage and Retrleval System (WATSTORE) of the U.S. Geological Survey (*). In addition, greater emphasis will be placed on the manual encoding and input of information on water data available from member organizations and the development of additional computerized interfaces with member data systems.

5. Software for producing summary statistics of the contents of the MWDI will be acquired and implemented (*).

6. Instructions, formats, and guidelines to aid members in developing automated procedures for indexing water data contained in their systems in the MWDI will be provided (*).

7. Participants will be provided with a complete listing of information on water-data collection activities contained in the MWDI for their organization for review and updating. 


\section{PROGRAM AND SYSTEMS DOCUMENTATIOA}

The Program office will make its program and systems documentation more widely available to the membership in order to assure better understanding of the program and its technical systems (*). An annotated bibliography of all NAWDEX documents is being prepared and will be made available in early fiscal Year 1979. To date, no technical systems documentation has been formally published by NAWDEX for public distribution. This will be accomplished to the greatest extent possible with available resources during Fiscal Year 1979.

\section{RECOMAENDED METHODS FOR THE HANDLING AND EXCHANGE OF WATER DATA}

The development of recommended standards for the handling and exchange of water data was addressed at the First NAWDEX Membership Conference. The ad hoc panel assigned to this task recommended that the term "methods" be adopted for this activity instead of the term "standards". Based upon the recommendations of this panel, the following actions will be taken during Fiscal Year 1979:

1. In ad hoc working group is planned to be developed fointly with the Federal Coordinating Council for Water Data Acquisition Methods and non-Federal Working Group on Recommended Methods established under the auspices of the Office of Water Data Coordination of the U.S. Geological Survey. This method of development will assure continuity with the alreadydeveloped "Recommended Methods for Water-Data Acquisition" and provide a mechanism for close coordination between these two activities. The ad hoc working group will consist of NAWDEX member representatives and, possibly, representatives of other organizations interested in water resources data. Upon its establishment, a detalled charter for the group will be developed and distributed to the membership.

2. The ad hoc working group will work toward the development of recommended optimal methods for the handling and exchange of water data using the following general specifications:

(a) Data Handling - Methods relating to the identification of data held by organizations, and site location of the data.

(b) Data Exchange - Methods relating to providing data to a user by the organization collecting and holding the data.

3. The ad hoc working group will initially address the following items:

a. Federal Information Processing Standards (FIPS)

b. Hydrologic Unit Codes 
c. Site Location Identifiers (Latitude-Longitude, local Identifiers, etc).

d. Data Access Capabilities

e. Common Data-Exchange Formats

$f$. Existing methods of data handling and exchange that may be appropriate for endorsement and use.

4. The ad hoc working group will also establish a timetable for meeting its objectives, establish publication criteria for the publication of the recommended methods, and develop review and input mechanisms. A report of its progress will be presented at the 1979 Membership Conference.

\section{TRAINING}

The NAWDEX Program office will conduct two training sessions during Fiscal Year 1979 (one each in Denver, Colorado and Reston, Virginia) for the continued orientation and training of Local Assistance Center personnel in NAWDEX systems, procedures, and capabilities. The Program office is also planning four regional training sessions during Fiscal Year 1979 for general membersh1p participation. These sessions are planned for Reston, Virginia; Atlanta, Georgla; Denver, Colorado; and Menlo Park, California. They will consist of general orientation about NAWDEX systems and capabilities and instruction in the encoding of data for indexing purposes. The Program office will pay the cost of Instructors and meeting facilities for these sessions. However, NAWDEX does not have funding for travel and subsistence of member representatives. This cost must be borne by member organizations. Th1s membership training was recommended by participants of the First NAWDEX Membership Conference but it will be conducted only if member interest warrants the activity. The membership will be polled in early Fiscal Year 1979 to determine interest and a decision will be made after the poll as to whether or not to schedule the training.

\section{TECHNICAL ASSISTANCE}

Although the Program office has a limited staff, it will continue its practice of providing technical assistance to members in the use of NAWDEX systems, developing indexing procedures and interfaces, and implementing the NAWDEX structure and concept. HAWDEX personnel will, as avallable, provide program orientation and systems demonstrations and participate in technical and professional conferences and meetings.

\section{SUMMARY}

All suggestions and recommendations offered at the First Membership Conference, probably, cannot be adopted in Fiscal Year 1979. The Program Office will, however, address as many of the suggested actions as funds and staff resources will allow. It is the intention of the NAWDEX Program office to conduct the management of the NAWDEX program in a responsive, flexible 
manner. The objectives in this report are, therefore, considered to be major goals for the forthcoming year. Objectives and tasks will be amended, as deemed necessry, to achieve maximum benefit from program resources and to meet short-term and unantioipated needs. 
•
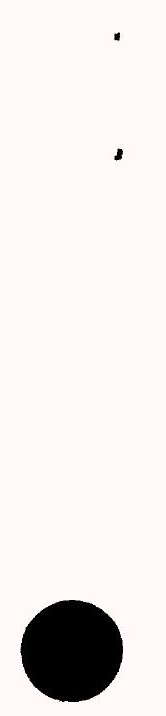